\title{
EFEKTIFITAS METODE PEMBELAJARAN DAN KEMAMPUAN MOTORIK DASAR TERHADAP KETERAMPILAN DRIBLING BOLA PADA SISWA SD
}

\author{
Saifu Alihasan \\ Jurusan Pendidikan Olahraga dan Kesehatan FKIP-UHO Kendari. \\ J1. H.E. Mokodompit Kendari \\ Email: syaifulpendor@gmail.com
}

\begin{abstract}
: this research aimed at describing the effectivity of teaching method and basic phisical act toward dribling ball skill in football section of elemenary students. This research was done by using exprimental study. The analysis of the data used Anava 2 ways method. The result showed that: (1) there are significant differences of dribling ball skill between the students who taught by applying drilling method and TAKTIS. (2) A drilling method in groups which have higher motoric than TAKTIS method. (3)There are no significant differences in groups of low basic phisical act that is taught with drilling teaching method and TAKTIS method. (4) There are no influences factors of interaction beween teaching method with basic motoric ability toward dribling skill in football.
\end{abstract}

Keywords: teaching method, basic motoric, dribling ball.

\begin{abstract}
Abstrak: Penelitian ini bertujuan mengetahui efektivitas metode pembelajaran dan kemampuan gerak dasar terhadap keterampilan dribling permainan sepak bola siswa SD. Penelitian ini menggunakan metode eksperimen. Analisis data menggunakan Anava 2 jalur. Hasil: (1) terdapat perbedaan signifikan keterampilan dribling permainan sepak bola antara siswa yang diajar dengan metode drill dengan siswa yang diajar dengan metode pembelajaran taktis. (2) Metode drill pada kelompok berkemampuan motorik tinggi lebih dari metode taktis. (3) Tidak terdapat perbedaan signifikan pada kelompok berkemampuan gerak dasar rendah antara kelompok siswa yang diajar dengan metode pembelajaran drill dengan siswa yang diajar dengan metode pembelajaran taktis. (4) Tidak terdapat pengaruh faktor interaksi antara metode mengajar dengan kemampuan motorik dasar terhadap keterampilan dribling permainan sepak bola.
\end{abstract}

Kata kunci: Metode pembelajaran, motorik dasar, dribling bola.

Pendidikan jasmani merupakan salah satu alat yang sangat penting untuk merangsang pertumbuhan dan perkembangan manusia, karena pendidikan jasmani sangat erat kaitannya dengan gerak manusia. Gerak bagi manusia sebagai aktivitas jasmani merupakan salah satu kebutuhan hidup yang sangat penting, yaitu sebagai dasar bagi manusia untuk belajar, baik untuk belajar mengenal alam sekitar dalam usaha memperoleh berbagai pengalaman berupa pengetahuan dan keterampilan, nilai dan sikap, maupun untuk belajar mengenali dirinya sendiri sebagai makhluk individu dan makhluk sosial dalam usaha penyesuaian dan mengatasi perubahanperubahan yang terjadi di lingkungannya dan untuk mencapai kesuksesan.

Suryobroto (2015) menyebutkan bahwa pendidikan jasmani di sekolah akan membantu pertumbuhan dan perkembangan siswa. Pertumbuhan dan perkembangan secara fisik ini membutuhkan peran segala pihak, termasuk guru. Oleh 
karena itu, apabila pengajaran pendidikan jasmani yang diselenggarakan di Sekolah Dasar (SD) dapat terorganisasikan dengan baik akan dapat memberikan sumbangan yang sangat berarti bagi pertumbuhan dan perkembangan murid-murid di $\mathrm{SD}$, baik pertumbuhan dan perkembangan jasmani dan rohani yang harmonis, maupun dalam rangka menyiapkan murid-murid secara psikologis yang mengarah kepada usaha-usaha keras yang sangat berguna untuk meningkatkan kemantapan jasmani dan rohani dalam membantu mengembangkan kemampuan dan kepribadian yang sangat besar pengaruhnya terhadap penyesuaian diri di dalam lingkungannya.

Wujud dari pelaksanaan pengajaran pendidikan jasmani di SD berpangkal pada gerak murid, yang menampakan dirinya ke luar terutama dalam bentuk-bentuk aktivitas jasmaninya. Aktivitas jasmani bukanlah semata-mata hanya berfungsi untuk merangsang dan mengembangkan organ-organ tubuh serta fungsinya saja, melainkan juga demi pembentukan dan pengembangan kepribadian yang utuh dan harmonis di dalam kehidupannya. Hal ini dalam rangka membentuk manusia pembangunan yang dapat membangun dirinya sendiri dan yang secara bersama-sama bertanggung jawab atas pembangunan bangsa. Oleh sebab itu, apabila program pendidikan jasmani yang diterapkan di SD dapat dilaksanakan sebagaimana mestinya dengan diarahkan, dibimbing, dan dikembangkan secara wajar, maka akan dapat menjadi bagian yang sangat penting bagi kehidupan murid dan akan sangat berarti serta bermanfaat dalam pendidikan. Untuk mencapai tujuan yang diharapkan, diperlukan strategi dan metode pembelajaran yang tepat agar tujuan dapat tercapai. Sunhaji (2008) menyatakan bahwa strategi pembelajaran merupakan rincian dari seleksi pengurutan peristiwa dan kegiatan dalam pembelajaran yang terdiri dari metode-metode, teknik-teknik, maupun prosedur-prosedur yang memungkinkan siswa mencapai tujuan.

Fakta di lapangan menunjukkan guru-guru penjas di SD umumnya masih menggunakan metode yang monoton yang berpusat kepada guru. Hal ini menyebabkan murid tidak dapat sepenuhnya mengembangkan kreatifitasnya baik pengembanagan kognitif, psikomotor maupun pengembangan afektifnya serta menimbulkan kebosanan pada murid. Untuk mengatasi hal ini, di samping penerapan metode yang sesuai, juga harus ditunjang oleh kemampuan motorik dasar dari peserta didik, yang meliputi kekuatan, kecepatam, kelincahan, keseimbangan dan kelenturan fisik. Rismayanthi (2013) mengungkapkan bahwa kemampuan motorik dasar ini merupakan merupakan aspek penting bagi anak didik. Kemampuan ini eprlu dikembangkan melaui aktivitas fisik yang dapat memberikan stimulasi termasuk melalui gerakan-gerakan pokok bahasan yang diajarkan oleh guru..

Berdasarkan fakta tersebut, maka yang menjadi fokus permasalah dalam penelitian ini adalah metode pembelajaran penjas siswa sekolah dasar, dengan pokok bahasan permainan. Menurut Moston (1994:4) metode mengajar dalam pendidikan jasmani terdiri dari dua kelompok yaitu metode mengajar langsung yang terdiri dari metode komando, metode latihan (drill), metode resiprokal dan metode inkuiri, sedangkan metode tidak langsung adalah metode eksplorasi dan metode divergen.

Pembelajaran yang dipilih dalam penelitian ini adalah keterampilan dribbling pada permainan sepak bola. Penentuan pembelajaran ini didasarkan pada karakteristik teknik permainannya yang kompleks yaitu ada unsur gerak lokomotor, non lokomotor dan gerak manipulatif. Gerak tersebut bermanfaat dan dibutuhkan anak usia SD dalam kehidupan sehari-hari. Di samping itu, kurikulum penjas di SD lebih banyak mengutamakan materi permainan.

Metode pembelajaran yang dipilih dalam penelitian ini adalah metode drill dan metode pembelajaran taktis. Metode mengajar drill adalah suatu metode mengajar, dimana siswa diajak ketempat latihan keterampilan untuk melihat bagaimana cara membuat sesuatu, bagaimana cara menggunakannya, untuk apa dibuat, apa manfaatnya dan sebagainya (Nasution, 2009:45). Moston (1994:58) menambahkan bahwa metode drill merupakan salah satu metode mengajar yang cocok diterapkan dalam pendidikan jasmani karena memiliki beberapa manfaat, antara lain: guru akan mempunyai peluang untuk mengajar dalam jumlah siswa yang banyak sekaligus; siswa belajar untuk bisa bekerja secara mandiri; siswa mempelajari konsekuensi atas keputusan yang mereka buat sesuai dengan ketentuan yang ada; siswa belajar mengenai keterbatasan waktu; siswa belajar mengenai sasaran yang harus dicapai dengan melaksanakan tugastugas tertentu; dan siswa memiliki kesempatan 
untuk meningkatkan interaksi individual dengan setiap siswa lainnya.

Metode drill memberikan siswa waktu untuk melaksanakan tugas secara perorangan, sedangkan guru memberi umpan balik kepada semua siswa secara perorangan. Disini guru bertanggung jawab menentukan tujuan pengajaran, memilih aktivitas dan menetapkan tata urut kegiatan untuk mencapai tujuan pengajaran. Metode drill sangat sesuai untuk pembelajaran dalam penguasaan teknik dasar. Di dalam metode ini siswa ikut serta menentukan cepat lambatnya tempo belajar, maksudnya guru memberikan keleluasaan bagi setiap siswa untuk menentukan sendiri kecepatan belajar dan kemajuan belajarnya. Guru tidak menghiraukan bagaimana organisasi kelas, atau apakah siswa melakukan tugas itu secara serempak atau tidak karena hal itu tidak begitu penting baginya. Tugas dapat disampaikan secara lisan atau tulisan. Siswa melakukan tugas sesuai dengan kemampuannya dan juga dapat dibantu oleh temannya, atau tugas itu dilaksanakan dalam sebuah kelompok kecil.

Metode pembelajaran taktis (Teaching Game For Understanding) adalah suatu metode pembelajaran dimana siswa yang belajar tidak diarahkan secara khusus dalam bagian-bagian teknik yang terpisah, akan tetapi diarahkan dalam suasana permainan yang sesungguhnya (Subroto, 2010:4). Melalui metode pembelajaran taktis ini kesadaran siswa akan konsep permainan ditingkatkan, waaupun dalam penerapannya dibutuhkan teknik yang tepat dengan masalah atau situasi dalam permainan. Yunyun (2010:13) menjelaskan bahwa untuk mengajarkan suatu bentuk permainan dalam olahraga, pendekatan taktik lebih baik dari pendekatan teknik. Metode pembelajaran taktis dapat meningkatkan kemampuan dalam mengambil keputusan taktis dibanding dengan metode pembelajaran teknis. Pada bermain secara taktis ini, siswa diarahkan kepada kemampuan untuk mengidentifikasi masalah-masalah taktis yang muncul selama dalam permainan, dan sekaligus dapat memilih respon yang tepat untuk memecahkannya. Respon tersebut dapat berupa pada keterampilan menguasai bola, seperti pada teknik dribbling pada permainan sepak bola.

Nopembri (2012:11) menjelaskan bahwa beberapa hal yang diperoleh melalui metode pembelajaran taktis antara lain adalah: mendorong pendekatan holistik kepada pengajaran permainan, mengembangkan berfikir kritis, dan pemecahan masalah, mengembangkan pengetahuan dan pemahaman bermain, mempromosikan tingkat partisipasi dan kesenangan untuk pesrta didik, mempromosikan pembelajaran yang terpusat kepada pemain dan relevansinya kepada keterampilan dan taktik, pemenuhan bermacam-macam kemampuan, dan membantu mengembangkan aspek implementasi. Metode Pembelajaran Taktis secara skematis digambarkan berikut.

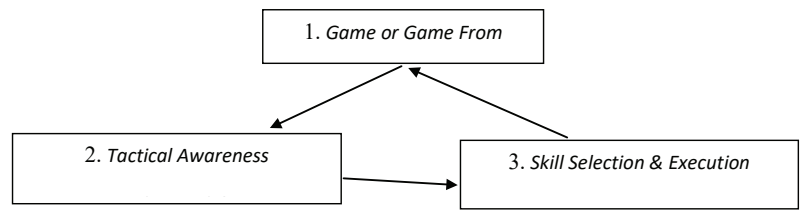

Tactical Game Model Griffin dan Oslin, dalam Yunyun, (2010:24)

Pada gambar tersebut di atas, diilustrasikan bahwa dalam bermain siswa sebelum mengeksekusi gerakan terlebih dahulu memperhatikan kondisi bola yang mengarah kepadanya, kemudian siswa memilih dan menyeleksi gerakan apa yang digunakan.

\section{METODE}

Jenis penelitian ini adalah penelitian eksperimen dengan menggunakan rancangan faktorial $2 \times 2$. Subjek penelitian adalah siswa kelas IV, V dan VI SD Negeri 23 Kendari Barat tahun ajaran 20132014 sebanyak 68 orang berjenis kelamin lakilaki. Teknik pegambilan sampel yang dgunakan adalah purposive sampling. Adapun prosedurnya adalah, dari jumlah 68 siswa kemudian diberi tes kemampuan motorik dasar dan selanjutnya hasilnya dirangking skor tertinggi ke rendah. Selanjutnya sampel yang memiliki kategori motorik tinggi diambil sebanyak $27 \%$ dan kategori motorik rendah juga diambil sebanyak 27\% (Verducci, 1980:176). Sehingga diperoleh sampel sebesar 32 siswa, yang terdiri dari 16 orang kategori motorik tinggi dan 16 orang siswa kategori motorik rendah. Masingmasing diberi pembelajaran metode $d r i l l$ dan metode pembelajaran taktis. Untuk mengukur keterampilan dribbling digunakan tes unjuk kerja.

Data hasil penelitian dianalisis dengan teknik statik deskriptif dan statistik inferensial. Statistik deskriptif dimaksudkan untuk mendeskriptifkan 
karakteristik skor responden untuk masingmasing variabel. Sedangkan statistik inferensial dimaksudkan untuk menguji hipotesiss penelitian dengan menggunakan uji ANAVA dua jalur.

\section{HASIL}

\section{Deskripsi Variabel Penelitian}

Data keterampilan dribbling pada permainan sepak bola pada kelompok siswa yang memiliki kemampuan motorik tinggi dan rendah dengan metode pembelajaran drill dan metode pembelajaran taktis seperti pada tabel 1.

Keterampilan dribbling permainan sepak bola untuk kelompok siswa yang diajar dengan metode mengajar drill secara keseluruhan memiliki rentang skor 6,00-9,00. Keterampilan dribbling sepak bola dalam kelompok ini mempunyai skor ratarata sebesar 7,67, skor modus 7,00, skor median sebesar 8,00, standar deviasi sebesar 0,84 , varians 0,71 , dan range 3,00. Sedangkan keterampilan dribbling permainan sepak bola kelompok siswa diajar dengan metode pembelajaran taktis secara keseluruhan memiliki rentang skor 6,00-8,00. Keterampilan dribbling sepak bola dalam kelompok ini mempunyai skor rata-rata sebesar 7,17 , skor modus 7,00, skor median sebesar 7,00, standar deviasi sebesar 0,79, varians 0,62, dan range 2,00.

Keterampilan dribbling bola yang diajar dengan metode mengajar drill pada kelompok siswa yang memiliki kemampuan motorik dasar tinggi, secara keseluruhan memiliki rentang skor 7,00-9,00. Keterampilan dribbling bola dalam kelompok ini mempunyai skor rata-rata sebesar 8,00 , skor modus
8,00 , skor median sebesar 8,00, standar deviasi sebesar 0,67, varians 0,44 , dan range 2,00.

Keterampilan dribbling bola yang diajar dengan metode mengajar drill pada kelompok siswa yang memiliki kemampuan motorik dasar rendah, secara keseluruhan memiliki rentang skor 6,00-8,00. Keterampilan dribbling bola dalam kelompok ini mempunyai skor rata-rata sebesar 7,11, skor modus 7,00 , skor median sebesar 7,00 , standar deviasi sebesar 0,60, varians 0,36, dan range 2,00.

Keterampilan dribbling bola yang diajar dengan metode pembelajarn taktis pada kelompok siswa yang memiliki kemampuan motorik dasar tinggi, secara keseluruhan memiliki rentang skor 7,00-8,00. Keterampilan dribbling bola dalam kelompok ini mempunyai skor rata-rata sebesar 7,67 , skor modus 8,00 , skor median 8,00 , standar deviasi sebesar 0,50 , varians 0,25 , dan range 1,00. Sedangkan keterampilan dribbling bola yang diajar dengan metode pembelajaran taktis pada kelompok siswa yang memiliki kemampuan motorik dasar rendah, secara keseluruhan memiliki rentang skor 6,00-8,00. Keterampilan dribbling bola dalam kelompok ini mempunyai skor rata-rata sebesar 6,67 , skor modus 6,00 , skor median 7,00, standar deviasi sebesar 0,70 , varians 0,50 , dan range 1,00.

\section{Perbedaan Pengaruh Perlakuan}

Hasil analisis dengan uji Analisis Varians Dua Jalur dengan Interaksi (ANAVA 2x2). Hasil perhitungan ditunjukkan pada Tabel 2.

Berdasarkan hasil analisis varians dalam Tabel 2 di atas, dapat dijelaskan sebagai berikut.

Tabel.1. Nilai Statistik Skor Keterampilan Dribling Permainan Sepak Bola

\begin{tabular}{lllllllll}
\hline Kelompok & $\bar{x}$ & Mo & Me & $\mathbf{s}$ & $\mathbf{s}^{\mathbf{2}}$ & Min & Max & Range \\
\hline $\mathbf{Y}_{1}$ & 7,67 & 7,00 & 8,00 & 0,84 & 0,71 & 6,00 & 9,00 & 3,00 \\
$\mathbf{Y}_{2}$ & 7,17 & 7,00 & 7,00 & 0,79 & 0,62 & 6,00 & 8,00 & 2,00 \\
$\mathbf{Y}_{11}$ & 8,22 & 8,00 & 8,00 & 0,67 & 0,44 & 7,00 & 9,00 & 2,00 \\
$\mathbf{Y}_{12}$ & 7,11 & 7,00 & 7,00 & 0,60 & 0,36 & 6,00 & 8,00 & 2,00 \\
$\mathbf{Y}_{21}$ & 7,67 & 8,00 & 8,00 & 0,50 & 0,25 & 7,00 & 8,00 & 1,00 \\
$\mathbf{Y}_{22}$ & 6,67 & 6,00 & 7,00 & 0,71 & 0,50 & 6,00 & 8,00 & 2,00 \\
\hline
\end{tabular}

Keterangan Tabel 1: (a) $\mathrm{Y}_{1}=$ Skor keterampilan dribling dengan metode mengajar drill, (b) $\mathrm{Y}_{2}=$ skor keterampilan dribling dengan metode mengajar taktis,(c) $\mathrm{Y}_{11}=$ skor keterampilan dribling yang memiliki kemampuan motorik dasar tinggi dengan metode mengajar drill, (d) $\mathrm{Y}_{12}=$ skor keterampilan dribling yang memiliki kemampuan motorik dasar rendah dengan metode mengajar drill, (e) $\mathrm{Y}_{21}=$ skor keterampilan dribling yang memiliki kemampuan motorik dasar tinggi dengan metode mengajar taktis, (f) $\mathrm{Y}_{22}=$ skor keterampilan dribling yang memiliki kemampuan motorik dasar rendah dengan metode mengajar taktis. 
Tabel 2. Pengaruh Metode dan Kemampuan Motorik Dasar Terhadap Keterampilan Dribling Bola pada Permainan Sepak Bola

\begin{tabular}{llllll}
\hline Sumber Varians & $\mathrm{Db}$ & $\mathrm{JK}$ & $\begin{array}{l}\mathrm{RK}= \\
\mathrm{JK} / \mathrm{db}\end{array}$ & $\begin{array}{l}\mathrm{F}_{\mathrm{h}}= \\
\mathrm{RK} / \mathrm{RKD}\end{array}$ & $\mathrm{p}$-value \\
\hline Metode Mengajar (A) & 1 & 0.400 & 0,400 & 3,03 & 0,048 \\
$\begin{array}{l}\text { Kemampuan Motorik (B) } \\
\text { Interaksi (Bxk) }\end{array}$ & 1 & 10,028 & 10,028 & 25,79 & 0,000 \\
& 1 & 0.028 & 0,028 & 0,07 & 0,791 \\
\hline Error (E) & 32 & 12.444 & 0.292 & - & - \\
Total Dikoreksi (T) & 35 & 24,750 & - & - & - \\
\hline
\end{tabular}

Keterangan: $\mathrm{db}=$ derajat bebas sumber variansi. $\mathrm{JK}=$ Jumlah Kuadrat Sumber Variansi, $\mathrm{RK}=$ Rata-rata Jumlah Kuadrat Sumber Variansi, $R K D=$ Rata-rata Jumlah Kuadrat Dalam Kelompok, $F_{h}=$ Nilai $F$ hitung; $p$-value $=$ nilai peluang penerimaan hipotesi nol

Terdapat perbedaan pangaruh yang signifikan metode mengajar yang digunakan antara metode pembelajaran drill dan metode pembelajaran tsktis terhadap keterampilan dribbling bola dalam permainan sepak bola dimana nilai $p$-value $=0,048$ $<$ dari taraf signifikan a $=0,05$. Dengan kata lain, terdapat perbedaan dribbling bola pada permainan sepak bola antara siswa yang diajar dengan metode pembelajaran drill dengan siswa yang diajar dengan metode pembelajaran taktis. Terdapat perbedaan pangaruh yang signifikan tingkat kemampuan motorik dasar terhadap keterampilan dribbling bola pada permainan sepak bola dimana nilai $p$-value $=0,000<$ dari taraf signifikan $\mathrm{a}=0,05$. Dengan kata lain, terdapat perbedaan dribbling permainan bola pada permainan sepak bola antara siswa yang memiliki kemampuan motorik dasar tinggi dengan siswa yang memiliki kemampuan motorik dasar rendah. Tidak terdapat pengaruh yang signifikan faktor interaksi antara metode yang digunakan (metode pembelajaran drill dan metode pembelajaran taktis) dengan kemampuan motorik dasar (tinggi dan rendah) terhadap keterampilan dribbling bola pada permainan sepak bola, karena nilai $p$-value $=0,791$ yang lebih besar dari taraf signifikan $\mathrm{a}=0,05$.

\section{Hasil Pengujian Hipotesis}

Terdapat perbedaan pengaruh yang signifikan metode mengajar drill dengan metode mengajar eksplorasi terhadap keterampilan dribbling bola pada permainan sepak bola dimana nilai $\mathrm{F}$ hitung $=5,95$ dengan nilai $p$-value $=0,020$. Dengan menggunakan taraf signifikan $\mathrm{a}=0,05$ menunjukkan bahwa pengujian perbedaan antara kedua metode mengajar adalah signifikan karena nilai $p$-value $=0,020$ lebih kecil dari taraf signifikan $a=0,05$. Terdapat perbedaan pengaruh yang signifikan metode pembelajaran drill dengan metode pembelajaran taktis terhadap keterampilan dribbling bola pada permainan sepak bola bagi siswa yang memiliki kemampuan motorik dasar tinggi dimana diperoleh nilai $\mathrm{t}$ hitung $=2,90$ dengan nilai $p$-value $=0,045$. Dengan menggunakan taraf signifikan a $=0,05$ menunjukkan bahwa pengujian perbedaan antara kedua metode mengajar adalah signifikan karena nilai $p$-value $=0,045$ lebih kecil dari taraf signifikan $\mathrm{a}=0,05$.

Tidak terdapat perbedaan pengaruh yang signifikan metode pembelajaran drill dengan metode pembelajaran taktis terhadap keterampilan dribbling bola pada permainan sepak bola bagi siswa yang memiliki kemampuan motorik dasar rendah dimana nilai $\mathrm{t}$ hitung $=1,44$ dengan nilai $p$-value $=0,171$. Dengan menggunakan taraf signifikan a $=0,05$ menunjukkan bahwa pengujian perbedaan antara kedua metode mengajar adalah tidak signifikan karena nilai $p$-value $=0,171$ lebih besar dari taraf signifikan a $=0,05$. Tidak terdapat pengaruh interaksi antara metode yang digunakan dengan kemampuan motorik dasar terhadap keterampilan dribbling bola pada permainan sepak bola dimana nilai $\mathrm{F}_{\mathrm{h}}=0,07$ dengan $p$-value $=$ 0,791 . Karena nilai $p$-value $=0,791$ lebih besar dari taraf signifikan $\mathrm{a}=0.05$

\section{PEMBAHASAN}

Berdasarkan hasil penelitian ini, secara keseluruhan, tanpa memperhitungkan kemampuan motorik dasar tinggi dan kemampuan motorik dasar 
rendah yang dimiliki oleh siswa sebagai subyek penelitian, terdapat perbedaan pengaruh yang signifikan antara metode pembelajaran drill dan metode pembelajaran taktis terhadap keterampilan dribbling permainan sepak bola. Secara keseluruhan metode mengajar drill mempunyai pengaruh lebih baik daripada metode pembelajaran taktis terhadap keterampilan dribbling bola dalam permainan sepak bola. Demikian pula, secara spesifik pada kemampuan motorik dasar tinggi juga memberikan hasil bahwa metode mengajar drill mempunyai pengaruh lebih baik dari pada metode pembelajaran taktis terhadap keterampilan dribbling bola dalam permainan sepak bola. Namun pada kemampuan motorik dasar rendah tidak terdapat perbedaan pengaruh yang signfikan. Selain itu, faktor interaksi antara metode mengajar dengan kemampuan motorik dasar tidak memberikan pangaruh yang signfikan.

Hasil penelitian ini didukung oleh data dan hasil-hasil analisis statistik juga didukung oleh beberapa pendapat dan kajian teori. Prayadi dan Rachman (2013) menyebutkan kelebihan metode drill antara lain meningkatnya daya pikir dan kreativitas; meningkatkan mental; latihan yang bervariasi menurangi kebosanan saat latihan. Moston (1994:152) menambahkan bahwa metode pembelajaran drill mempunyai keunggulan sebagai berikut: (a) dapat untuk memperoleh kecakapan motorik terhadap materi yang dipelajari, (b) dapat untuk memperoleh kecakapan mental, dan sebagainya, (c) dapat membentuk kebiasaan dan menambah ketepatan dan kecepatan pelaksanaan.

Skill menggiring bola memang penting, tetapi pemain hendaknya tidak lupa bahwa menggiring bola sangat menguras tenaga dan sering kali memperlambat tempo permainan. Mielke (2007:35) menjelaskan beberapa prinsip yang harus diperhatikan dalam mengiring bola, antara lain: (1) giring bola dekat kaki, (2) giring bola dengan sisi luar bagian depan kaki sementara pinggul tetap mengarah lurus ke depan, (3) pemain berlatih mengubah arah giringan, menambah atau mengurangi kecepatan dalam menggiring bola dan sewaktu-waktu menghentikan bola.

Dalam pembelajaran pendidikan jasmani yang dikembangkan oleh guru penjas saat ini adalah strategi pembelajaran yang mudah dan terkesan masih tradisional dengan penggunaan metode demonstrasi sebagai satu-satunya metode mengajar. Pembelajaran metode drill akan membuat semua siswa terlibat dalam proses pembelajaran dengan jalan melakukan latihan-latihan sesuai dengan bentuk-bentuk latihan yang ada dalam lembaran tugas yang telah disiapkan oleh guru. Noviada, Kanca, \& Darmawan (2014) juga mengungkapkan bahwa metode taktis berpengaruh terhadap peningkatan keterampilan teknik dasar siswa. Pembelajaran dengan metode mengajar taktis dalam mata pelajaran pendidikan jasmani memungkinkan siswa untuk belajar dengan aktif, kreatif, inovatif, dan mandiri, karena dalam gaya mengajar taktis siswa diberi kebebasan untuk mengeksplorasi gerakan dalam bermain.

Peran guru dalam metode pembelajaran taktis ini hanya memberikan salah satu contoh gerakan, sedangkan gerakan-gerakan yang lain dapat dikembangkan siswa secara individu maupun kelompok, sesuai dengan kondisi dan situasi pada saat bermain. Pada pembelajaran taktis siswa memperoleh beberapa hal antara lain adalah: (1) mendorong pendekatan holistik kepada pengajaran permainan, (2) mengembangkan berfikir kritis, dan pemecahan masalah, (3) mengembangkan pengetahuan dan pemahaman bermain, (4) mempromosikan tingkat partisipasi dan kesenangan untuk pesrta didik, (5) mempromosikan pembelajaran yang terpusat kepada pemain dan relevansinya kepada keterampilan dan taktik, (6) pemenuhan bermacam-macam kemampuan, dan (7) membantu mengembangkan aspek implemen.

Kemampuan motorik merupakan faktor penting yang mendukung dalam melakukan aktifitas fisik. Kemampuan dasar motorik ini meliputi unsur kekuatan dan power, daya tahan, kelincahan serta keseimbangan gerak. Menurut Soekatamsi (2002:25), faktor utama yang menjadi persyaratan khusus bagi pemain sepak bola dalam menggiring bola adalah kelincahan dan keseimbangan tubuh. Lebih lanjut dikatakan bahwa kelincahan adalah kemampuan seseorang untuk dapat mengubah arah dengan cepat dan tepat pada waktu bergerak tanpa kehilangan keseimbangan. Kelincahan ini berkaitan erat antara kecepatan dan kelentukan. Tanpa keduanya seseorang tidak dapat bergerak dengan lincah. Pendapat tersebut di atas, jelas bahwa seorang pemain bola jika ingin menguasai bola dan men-dribbling bola dengan baik maka dia harus memiliki kelincahan (agility) tubuh yang baik. 
Perbedaan penyajian yang dilakukan dengan metode pembelajaran drill dan metode pembelajaran taktis, diasumsikan dapat memberikan efek yang berbeda. Pada metode mengajar drill, siswa dituntut untuk berperan aktif dan mengulang pembelajaran dan tanggung jawab untuk mempelajari materi berupa lembaran tugas yang disediakan oleh guru. Siswa diberikan peranan untuk melakukan gerakan sesuai dengan tugas yang telah diberikan. Sedangkan pada metode pembelajaran taktis. Yunyun (2010:15) menjelaskan bahwa metode ini lebih menekankan pada penguasaan bermain seingga gerakan yang dilakukan sesuai dengan kondisi pada saat itu, tanpa direncanakan. Sedangkan peran guru menekankan pada pemberian kesempatan pada siswa seluasluasnya untuk mengembangkan kemampuannya atas usaha sendiri dan meminimalkan peran guru serta lebih berorientasi pada kebutuhan siswa sendiri (student centered).

Pengembangan metode drill dan metode taktis juga dapat dilakukan guru, seperti model latihan ketepatan tendangan dengan pendekatan bermain yang dikembangkan oleh Anam (2013). Model ini terbukti efektif dalam mengembangkan keterampilan passing bola di Sekolah Sepak Bola (SSB). Diputra (2015) juga menggunakan eksperimen untuk meningkatkan kelincahan dan kecepatan siswa dalam sepakbola. Metode latihan three cone drill, four cone drill, dan five cone drill yang digunakan memberikan alternatif guru dalam meningkatkan kemampuan siswa dalam sepakbola. Hal ini menunjukkan bahwa kreatifitas guru dalam mengembangkan metode pembelajaran penjas sangat berpengaruh terhadap keterampilan siswa dalam menguasai teknik-teknik olahraga.

\section{SIMPULAN DAN SARAN}

\section{Simpulan}

Kesimpulan dalam penelitian ini adalah: (1) Terdesimpulan dalam penelitian ini adalah terdapat perbedaan yang signifikan pada keterampilan dribbling pada permainan sepak bola antara kelompok siswa yang diajar dengan metode pembelajaran drill dengan kelompok siswa yang diajar dengan metode pembelajaran taktis, kelompok siswa yang diajar dengan metode drill memiliki keterampilan dribbling lebih baik dibandingkan dengan metode pembelajaran taktis; pada kemampuan motorik dasar tinggi, terdapat perbedaan yang signifikan keterampilan dribbling antara kelompok siswa yang diajar dengan metode pembelajaran drill dengan kelompok sisiwa yang diajar dengan metode pembelajaran taktis, kelompok siswa yang diajar dengan metode drill memiliki keterampilan dribbling bola lebih baik dibandingkan dengan metode pembelajaran taktis; pada kemampuan motorik dasar rendah, tidak terdapat perbedaan yang signifikan keterampilan dribbling bola pada permainan sepak bola antara kelompok siswa yang diajar dengan metode pembelajaran drill dengan kelompok sisiwa yang diajar dengan metode pembelajaran taktis, kedua metode ini memberikan keterampilan dribbling bola yang relatif sama; tidak terdapat pengaruh faktor interaksi antara metode mengajar dengan kemampuan motorik dasar terhadap keterampilan dribbling pada permainan sepak bola. .

\section{Saran}

Memperhatikan hasil penelitian, maka disarankan dalam melaksanakan pembelajaran keterampilan dribbling pada siswa SD sebaiknya guru menggunakan metode pembelajaran drill dan pada siswa berkemampuan motorik dasar yang baik, perlu diperhatikan peningkatannya oleh guru penjas agar mencapai hasil yang baik dalam proses mengajarnya.

\section{DAFTAR RUJUKAN}

Anam, K. 2013. Pengembangan Latihan Ketepatan Tendangan dalam Sepakbola untuk Anak Kelompok Umur 13-14 Tahun. Media Ilmu Keolahragaan Indonesia, 3(2):66-78.

Diputra, R. 2015. Pengaruh Latihan Three Cone Drill, Four Cone Drill, dan Five Cone Drill terhadap Kelincahan (Agility) dan Kecepatan (Speed). Jurnal Efektor, 27(7): 25-30.

Mielke, Danny. 2007. Belajar Bermain Bola. Jakarta: Raja Grafindo Persada.

Moston, Musska and Sara Asworth, 1994. Teaching Physical Education. New York: MacMillan College Publishing Company Inc.

Nasution, S. 2009. Berbagai Pendekatan dalam Proses Belajar dan Mengajar. Jakarta: PT. Bumi Aksara.

Nopembri, S.S. 2012, Model Pembelajaran Pendidikan Jasmani. Yogyakarta: Fakultas Ilmu Keolahragaan Universitas Negeri Yogyakarta. 
Noviada, G., Kanca, I. N., \& Darmawan, G. E. B. 2014. Metode Pelatihan Taktis Passing Berpasangan Statis dan Passing Sambil Bergerak terhadap Keterampilan Teknik Dasar Passing Control Bola Futsal. Jurnal Jurusan Pendidikan Kepelatihan Olahraga, 2(1):66-79.

Prayadi, H. Y., \& Rachman, H. A. 2013. Pengaruh Metode Latihan dan Power Lengan Terhadap Kemampuan Smash Bulutangkis. Jurnal Keolahragaan, 1(1), 63-71.

Rismayanthi, C. 2013. Mengembangkan Keterampilan Gerak Dasar sebagai Stimulasi Motorik bagi Anak Taman Kanak-Kanak melalui Aktivitas Jasmani. Jurnal Pendidikan Jasmani Indonesia, 9(1):12-24.

Soekatamsi. 2002. Permainan Bola Besar (Sepak Bola). Modul Perkuliahan S1 Universitas Terbuka Tahun 2002.
Subroto, T. 2010. Didaktik Metode Pembelajaran Olahraga Permainan. Bandung: Universitas Pendidikan Indonesia.

Sunhaji. 2008. Strategi pembelajaran: Konsep dan aplikasinya. Journal Pemikiran Alternatif Pendidikan. 13(3):474-492.

Suryobroto, A. S. 2015. Peningkatan Kemampuan Manajemen Guru Pendidikan Jasmani. Jurnal Pendidikan Jasmani Indonesia, 1(1): 12-24.

Yunyun, Y. 2010. Impelmentasi Model Pendekatan Taktis dan Teknis untuk Pembelajaran Permainan Bola Basket. Disertasi Doktor pada Sekolah Pasca Sarjana UPI, Bandung.

Verducci, Frank M. 1980. Measurement Concept in Physical Education. London: The C.V. Mosby Company. 
